\title{
By their teeth shall ye know them
}

\author{
M. E. Richardson, '
}

\section{These extracts from the literary archive focus on the role of teeth as a facial feature. Their contribution to favourable and unfavourable facial appearance by their presence or absence, their use as a guide to character and as a means of identification are illustrated.}

$\mathrm{T}$ eeth are an important feature of the human face. Scarcely less cognisant of this fact than the dental profession is the writer. Generations of biographers, novelists, poets, playwrights, essayists and journalists have included descriptions of teeth in portraying the facial appearance of their characters. Some are aesthetically pleasing, others less so.

\section{Beautiful teeth}

Anthony Trollope's ' 'Lucy Robarts was thoroughly a brunette. Sometimes the dark tint of her cheek was exquisitely rich and lovely, and the fringes of her eyes were long and soft, and her small teeth, which one so seldom saw, were white as pearls, and her hair, though short, was beautifully soft - by no means black, but yet of so dark a shade of brown. Blanche, too, was noted for fine teeth. They were white and regular and lofty as a new row of houses in a French city. But then when she laughed she was all teeth; as she was all neck when she sat at the piano. But Lucy's teeth! - it was only now and again, when in some sudden burst of wonder she would sit for a moment with her lips apart, that the fine finished lines and dainty pearl-white colour of that perfect set of ivory could be seen.'

In Gustave Flaubert's ${ }^{2}$ Letters occurs a self-portrait of Louise Colet 'My mouth is small, fresh-looking, though not remarkable in shape. My smile is particularly pleasantkindly, naive, I am told: I have never seen myself smile. My teeth are beautiful, in excellent condition, and I have all of them except

\footnotetext{
${ }^{1 *}$ Associate Specialist Orthodontist (retired), 33 Cherryvalley Park, Belfast BT5 6PN N Ireland ${ }^{*}$ Correspondence to: Margaret Richardson REFEREED PAPER

Received 22.03.01; Accepted 02.05.01

(C) British Dental Journal 2001; 191: 459-464
}

one rear molar that I had extracted, being unable to stand the pain'.

It is debatable if the wife of Osbert Sitwell's $s^{3}$ headmaster qualifies for this category 'Concolorous, she was dressed in a gown of beige lace, which matched exactly her eyes and complexion, and the effect was completed by a large beige hat, with a beige ostrich feather running round the brim, under which showed a small, curly beige fringe. "She's such a pleasant looking little woman, with her nice smile", the parents used to say, in order to damp unpleasant doubts, "not pretty exactly, perhaps, but such a nice way of showing her teeth when she laughs." (Behind her back, the boys called her 'Tusker.'.)'

Black teeth, I decided, were preferable to red or even to yellow ones, and I could see myself getting used to them in time Ugly teeth
Unsightly teeth seem to catch the imagina-
tion of the writer to a greater extent. They
can disfigure an otherwise beautiful face as
described by Harold Acton. 'The Annamese
attendants were lithe and sleek and silky.
Their features were as delicate as those of Chi-
nese beauties but they were less expressive.
Their mouths were often marred by an array
of black lacquered teeth. As in Java and Bali,
many of them chewed betel, which stained
their teeth and lips a sinister bleeding crim- son. Black teeth, I decided, were preferable to red or even to yellow ones, and I could see myself getting used to them in time. As for the flavour of betel, it affected me like an unpleasantly astringent toothpaste which puckered up my mouth. A tube of Pepsodent would have been more refreshing.'

David Garnett's ${ }^{5}$ imagination was similarly fired 'Dorothy was short and rather fat, with a buxom low-breasted figure which was not improved by her square-cut low-necked, clumsy home-made dresses and her lack of any form of corset or brassiere. She had a beautiful complexion and a white skin, lovely challenging blue eyes, a noble forehead and very fine fair hair which was screwed up into a small bun at the back. But her beauty was spoilt by prominent, protruding upper teeth which were not only ugly in themselves, but spoilt what might have otherwise been pretty lips.'

Ugly teeth can compound an already unpleasing appearance as in Luigi Barzini's 6 description of Mussolini 'My first impression of him, years later in 1932, during some army manoeuvres, was a disturbing one. He wore a white yachting cap, a wing collar, the doublebreasted jacket of a businessman, grey-green army breeches, and black boots. He looked like a circus performer in off hours. Perhaps his clothes were meant to symbolise the multifarious variety of his interests: horses, business, the sea, the economic life of the nation, and the army. He looked small, thick, rude, and stubborn. I remember the large ivorycoloured bald head, the bulging black eyes in the pale face, the protruding jaw, the yellow teeth set wide apart (a sign of good luck, according to popular belief), a little potatolike excrescence on his cranium, and the large black mole under his chin. He moved his arms and legs as a wrestler does to make his clothes fit better.'

Kenneth Toomey's literary agent in Anthony Burgess's novel Earthly Powers ${ }^{7}$ :... was about thirty and totally, one could say obscenely bald; he had achieved, I understood, this state while only twenty and still at Cambridge and dreaming about becoming a great novelist. He had blistered meaty lips and a pronounced diastema, the top incisors inclining 
left and right, the consequence of thumbsucking as a child, The interdental gap accommodated a cigarette like a Panglossian holder; he tended, as now, to forget it was there, going damn and blast when his lips scorched.'

Oscar Wilde does not fare well at the mercy of Frank Harris's' 8 pen. 'I went with her and was formally introduced to him. He shook hands in a limp way I disliked; his hands were flabby, greasy; his skin looked bilious and dirty. He wore a great green scarab ring on one finger. He was overdressed rather than well-dressed; his clothes fitted him too tightly; he was too stout. He had a trick which I noticed even then, which grew on him later, of pulling his jowl with his right hand as he spoke, and his jowl was already fat and pouchy. His appearance filled me with distaste. I lay stress on this physical repulsion, because I think many people felt $i t$, and in itself, it is a tribute to the fascination of the man that he should have overcome the first impression so completely and so quickly. I don't remember what we talked about, but I noticed almost immediately that his grey eyes were finely expressive; in turn vivacious, laughing, sympathetic; always beautiful. The carven mouth, too, with its heavy, chiselled, purpletinged lips, had a certain attraction and significance in spite of a black front tooth which shocked one when he laughed. He was over six feet in height and both broad and thick-set; he looked like a Roman Emperor of the decadence.'

Sean O'Faolain's 9 'Aunt Maggie was equally tall and strong-shouldered, with a round, bellowing voice that you could hear two fields away, and teeth that could plough the earth; a dark rough woman whom nobody would want to cross.'

Teeth may be unsightly because of poor oral hygiene, neglected caries and discolouration, wonderfully depicted by Arthur Calder-Marshall ${ }^{10}$ 'His face had never 'fined out'; it had the blobbiness found in many children during the first two years of life. And his teeth were very bad. They were dark brown towards the roots and there was some argument about whether their colour was predominantly yellow or green, and whether their texture was harsh, furry or slimy. Yet there was no doubt how bad anyone with a hangover felt when he said, "I feel like Hugh's teeth."

Joyce Cary ${ }^{11}$ likewise described his character Oweny. 'Sometimes we had gone to row with them, and as we could not alone manage the long sweeps, we sat on the same thwarts, Harry with Roe, and I with Oweny, tugging and pushing. But we found these trips slow, for the old man never spoke; and Oweny would only grin and spit over the side between his broken teeth. At sixteen Oweny's teeth were already broken and black.

was always curious about Oweny. I used to ask him: "Did you have a good breakfast, Oweny?"

"Oh, aye, a drink of buttermilk and a sup of good air."

"Why are your teeth so black, Oweny?"

"Ah, who wants teeth? - they're only in your way." '

\section{Aunt Maggie was equally tall and strong- shouldered, with a round, bellowing voice that you could hear two fields away, and teeth that could plough the earth}

The possible repercussions of ugly teeth are highlighted by Mikhail Sholokhov. ${ }^{12}$ 'Ilinichna's shrewd widow cousin, auntie Vasilisa, was to go with them as matchmaker. She was the first to nestle herself into the wagonette, twisting and turning her head, laughing, and displaying her crooked black teeth beneath the pucker of her lips. "Don't show your teeth, Vasilisa," Pantaleimon warned her. "You'll ruin everything with your gap. Your teeth are set all drunk in your mouth; one one way and one the other..."

"Ah, dad, I'm not the bridegroom to be." "Maybe you're not, but don't laugh all the same."

J. D. Salinger's ${ }^{13}$ neighbour '... was one of those very, very tall, round-shouldered guyshe was about six-four - with lousy teeth. The whole time he roomed next to me, I never even once saw him brush his teeth. They always looked mossy and awful, and he damn near made you sick if you saw him in the diningroom with his mouth full of mashed potatoes and peas or something. Besides that, he had a lot of pimples. Not just on his forehead or his chin, like most guys, but all over his whole face. And not only that, he had a terrible personality. He was also sort of a nasty guy. I wasn't too crazy about him, to tell you the truth.'

Siegfried Sassoon's ${ }^{14}$ 'Mr Farrell was a retired Civil Servant and an authority on Military Records. He had written the lives of several famous Generals and an official History of the Indian Mutiny. But he showed no curiosity about the military operations of the moment. He was over seventy, and his face was unlit and fatigued as he talked about food restrictions in England. "Sugar is getting scarce," he remarked, "but that doesn't affect me; my doctor has knocked me off sugar several years ago." I looked at his noticeably brown teeth, and then averted my eyes as if he could read my thoughts, for I was remembering how Aunt Evelyn used to scold me for calling him "sugar-teeth"; his untidy teeth did look like lumps of sugar soaked in tea.'

V. S. Prichett's ${ }^{15}$ 'Great uncle Arthur was a stunted and bandy man, with a dark, sallow and strong boned face. He looked very yellow.

He had a heavy head of wiry hair as black as coals, ragged eyebrows and a horrible long black beard like a crinkled mat of pubic hair. A reek of tobacco, varnish and wood-shavings came off him; he had large fingers with split unclean nails. The first thing he did when he got home from work was to put on a white apron, strap a pair of carpet knee-pads to his trousers, pick up a hammer or screw-driver and start on odd jobs round the house. He was always hammering something and was often up a ladder. His great yellow teeth gave me the idea he had a machine of some kind in his mouth, and that they were fit to bite nails; in fact he often pulled a nail or two out of his mouth. He seemed to chew them.

Uncle Arthur's wife was Grandma's eldest sister and in every way unlike her. She was tall, big boned, very white faced and hollow-eyed and had large, loose, laughing teeth like a horse's or a skeleton's which have ever since seemed to me the signs of hilarious good nature in a woman. Though she looked ill - breathing those fumes of the gas works which filled the 
house cannot have been good for her - she was jolly, hard-working and affectionate. She and Uncle Arthur were notorious (in the family) for the incredible folly of adoring each other. She doted on her dark, scowling, argumentative, hammering little gnome: it seemed that two extraordinary sets of teeth had fallen in love with each other.'

\section{She and Uncle Arthur were notorious (in the family) for the incredible folly of adoring each other.... it seemed that two extraordinary sets of teeth had fallen in love with each other}

Malocclusion, particularly crowding, gives rise to some wonderful descriptions of unsightly teeth such as Anne Tyler's 16 'Hewas grotesquely tall, as gaunt as the armature for some statue never completed. His cropped black hair bristled all over his head, his skull of a face glistened, and he clenched a set of teeth so ragged and white and crowded, so jumbled together and overlapping, that it seemed he had chewed them up and was preparing to spit them out...............his lips could barely close over that chaos of teeth; his mouth had a bunchy look and his chin was elongated from the effort. His long front teeth were so prominent that his lips had to labour to stretch across them. His whole face seemed stretched, and too intricately hinged at the jawbone.'

Gerald Brennan ${ }^{17}$ described an encounter with a similarly unfortunate individual. 'I am shivering on the edge of the swimming pool when a cry goes up, "Throw him in the deep end! Duck him!" A creature whose gums and teeth seem to be breaking out of his mouth like the seeds from a cracked pomegranate, says, "I'll pay you out." Hostile faces, hostile gestures, hostile words hem me in like those of the devils in a medieval painting. But they are not devils, only English schoolboys.. For example, I remember how with another boy (whose face comes down to me as an enormous red pear with a few rat-like teeth projecting from it) I used to creep into an empty lot of building-land that lay next to the railway cutting and which, because it was overgrown with bushes and strictly out of bounds, we called Noman's land.'

Patrick Leigh Fermor ${ }^{18}$ suggests the frightening effect of ugly teeth. 'Under tumbling blond curls his china blue eyes protruded from cheeks that might have been blown up with a bicycle pump, and cherry lips laid bare the sort of teeth that make children squeal.'

Facial contortions involving teeth are described by Patrick Leigh Fermor ${ }^{18}$ ' $I$ asked him what they looked like and he repeated the question ruminatively to himself. "Beastly!" he said at last. "You see, they have no scales, they are quite smooth. Dullcoloured and slimy. But the face! That's the thing! It has great blunt features and hateful little staring eyes." As he spoke, he lowered his brows in a scowl and somehow contrived to make the large frank eyes behind the lenses contract and protrude simultaneously in a glare of venomous rage - "and its mouth!" he went on, "its mouth is the worst of all! It's underslung and fitted with rows of terrifying little teeth." He widened his mouth to a slit that sank balefully at both ends and thrust out his lower jaw in a hideous Hapsburg jut. "And it has long whiskers," he said, spreading his finger-tips across both his cheeks, "sweeping out on either side." He fanned them airily away over his shoulders like the long barbels of the giant catfish streaming in the current. "It looks like this!" he said, slowly rising from his chair and, as he did so, he thrust the dreadful mask towards us across the wine glasses. It was as if the great fish had swum in silently through the door.'

\section{Expressive teeth}

Description of teeth to express character and behaviour was employed to great effect by Charles Dickens ${ }^{19}$ in portraying the obsequious and cunning lawyer in Dombey and Son. 'Mr Carker was a gentleman thirtyeight or forty years old, of a florid complexion, and with two unbroken rows of glistening teeth, whose regularity and whiteness were quite distressing. It was impossible to escape the observation of them, for he showed them whenever he spoke; and bore so wide a smile upon his countenance (a smile, however, very rarely, indeed, extending beyond his mouth), that there was something in it like the snarl of a cat. ......................... Carker bared himself to the tops and bottoms of his gums: making the watchful Toddle junior tremble more and more: and acknowledged the instrumentmaker's politeness in his most affable manner........... His smile at parting was so full of teeth, that it confused old Sol, and made him vaguely uncomfortable............ Mr Carker the manager did a great deal of business in the course of the day, and bestowed his teeth upon a great many people. In the office, in the court, in the street, and on 'Change they glistened and bristled to a terrible extent........

"If the dog's teeth have entered the leg, sir-" began Carker, with a display of his own.

.......Mr Carker the Manager, hat in hand, just arrived at Leamington, and just introduced to the major, showed the major his whole double range of teeth, and trusted he might take the liberty of thanking him with all his heart for having effected so great an improvement in Mr Dombey's looks and spirits ...

$\mathrm{Mr}$ Carker's excessively friendly inclinations towards the major, and Mr Carker's admiration of his roughness, toughness, and plainness, gleamed out of every tooth in $\mathrm{Mr}$ Carker's head ............Taking a nearer way back, Mr Carker pursued it, airing his teeth, and said aloud as he did so, "Now to see the second Mrs Dombey!"............."It is most extraordinary" said Carker, bringing every one of his red gums to bear upon his praise............ "May I be allowed, madam," said Carker, turning his white teeth on Mrs Skewton like a light ................. As he bent forward, to be nearer, with the utmost show of delicacy and respect, and with his teeth persuasively arrayed, in a self-depreciating smile, she felt as if she could have struck him dead.............But, Withers, meeting him on the stairs, stood amazed at the beauty of his teeth, and at his brilliant smile; and as he rode away 
on his white-legged horse, the people took him for a dentist, such was the dazzling show he made.'

C Day-Lewis's ${ }^{20}$ 'Uncle Willie, the Reverend W.G.Squires, was, I can see now, a fullblown eccentric. As a child, though, I accepted him with no astonishment whatsoever, swallowed him whole. His face was a caricature of a face: eyebrows black and thick as Groucho Marx's moustache, lantern jaw, mouth trembling on the brink of some profound and inaccessible humour, huge teeth stained by pipe-smoking - teeth whose movements when he ate seemed entirely unrelated to the movement of his jaw, as though he worked them independently by invisible strings. He ate noisily too, champing like a horse.

He conducted services in a wild caricature of the "parsonical" voice, m'nyuming and m'nyahing, making long pauses in the most inappropriate places, switch-backing down and up at the end of each sentence.

"We will now sing," he would enunciate, leaving a yawning gulf between the last and the penultimate word, "we will now sing the, m'nyah, one hundred and tenth....sam. One day I wrote a bloodcurdling message from the ghost in red ink on its wall, and brought Uncle Willie to see it. He stared aghast at the message: his huge teeth chattered as if they would break loose from the gums: a delicious terror seized me, so that I almost believed he believed a ghost had done it.'

In his memoirs entitled My Contemporaries Jean Cocteau ${ }^{21}$ wrote 'Serge Diaghilev wore what seemed to be the smallest hat in the world. If anyone else put it on it came down to their ears. For his head was so big that any headgear was too small for him. His dancers nicknamed him 'chinchilla', because of a single white strand in his hair, which otherwise had been dyed jet black. He used to bundle himself into a pelisse with an opossum collar and sometimes fastened it with safety pins. He had a face like a bull dog, and he smiled like a very young crocodile, with one tooth jutting outside his mouth. When he sucked this tooth it meant that he was either pleased, or worried, or angry.'

Thomas Hardy ${ }^{22}$ described teeth as an expressive feature in Under the Greenwood Tree. " "Hee- hee-ay!" replied Leaf, letting his mouth continue to smile for some time after his mind had done smiling, so that his teeth remained in view as the most conspicuous members of his body.'

\section{The maltser's lack of teeth appeared not to sensibly diminish his} powers as a mill. $\mathrm{He}$ had been without them for so many years that toothlessness was

\section{felt less to be a defect than hard gums an acquisition}

Leonard Woolf ${ }^{23}$ used teeth to lend a sinister appearance to a character 'Sometimes when one caught in a certain light the vision of his mouth and jaw, it gave one that tiny little clutch of fear in the heart. It made one think of Turgenev's mother flogging the servant to death. I have known only very few people with this kind of mouth; its sinister shape comes, I think, from the form of the jaw and arrangement of the teeth. There is always the shadow of a smile in it, but it is the baleful smile of the shark or a crocodile. Mirsky had this kind of smile. One day when I was travelling by train along the south coast of Ceylon from Marata to Galle, on the platform of one of the stations which we passed there were dozens of dead sharks. I had never seen any thing like it in Ceylon and I do not know why they were there. On each dead face there was this sinister grin. Talking to Mirsky in a London sitting-room, as he suddenly turned his head to say something and there was a glint of teeth and a smile, I was back in Ceylon twelve years ago in the railway carriage looking at rows of dead, smiling sharks.'

Jay Landesman ${ }^{24}$ reflected on how the appearance of his teeth influenced his career 'Did I mention that I had a black front tooth when I arrived on campus in January, 1938?
Funny how teeth play such a large role in one's freshman year. Students with perfect teeth seldom make perfect students; they tend to become, instead, very popular on campus. I had to thank Lefty O'Doyle, who hit me when I was drinking a coke, for whatever little academic success I had that first year. I survived not being invited to join the Jewish fraternity. When I wasn't asked to the informal tea or the Independent Student's League, though, I wondered if I could handle the social consequences. Luckily I lived in a boarding house with seven other students whose teeth were worse than mine. There was no way I was going to be a big man on campus with my smile, so I drifted towards a course in boxing where a black front tooth was an asset.'

\section{Missing teeth}

Lack of teeth is often incorporated in descriptions of facial expression notably by Thomas Hardy ${ }^{25}$ in Far from the Madding Crowd. " "Aye, sure," said his son, a young man of about sixty-five, with a semi-bald head and one tooth in the left centre of his upper jaw, which made much of itself by standing prominent, like a milestone in a bank.......

'The maltser's lack of teeth appeared not to sensibly diminish his powers as a mill. He had been without them for so many years that toothlessness was felt less to be a defect than hard gums an acquisition. Indeed, he seemed to approach the grave as a hyperbolic curve approaches a straight line - less directly as he got nearer, till it was doubtful if he would ever reach it at all.' Hardy continued this theme in The Trumpet Major ${ }^{26}$ :....he knew very well of that ploughed-ground appearance near the corners of her once handsome eyes, and that the little depression in her right cheek was not the lingering dimple it was poetically assumed to be, but a result of the abstraction of some wornout nether millstones within the cheek by Rootle, the Budmouth man, who lived by such practices on the heads of the elderly. But what of that, when he had lost two to each one of hers, and exceeded her in age by some eight years!'

Patrick Leigh Fermor ${ }^{18}$ noted the effect of partial and complete edentulousness on facial appearance 'She was very pretty except for two missing front teeth. They had been knocked out in a brawl the week before, she 
told me. ......... The smile of her totally dismantled gums had the innocence of an infant's'.

'The middles of faces are simultaneously flaccid and clenched, as though a bad diet had prematurely rotted away every tooth in their heads, and often, for no very clear reason, features start sliding out of shape. Noses fall askew, eyes grow bleary and mouths hang open like those of snowmen or village idiots. There is something enigmatic and unexplained about this spreading collapse. It has no bearing on the holiness or the villainy of the character affected and, clearly, nothing to do with technical capacity. It is as though a toxin of instability and dissolution had crept into the painter's brain.'

And Marcel Proust ${ }^{27}$ neatly described the effect of tooth loss on jaw function 'She had two remarkable habits, due at once to her exalted passion for the arts... and to her want of teeth. Whenever she talked of aesthetic subjects her salivary glands - like those of certain animals when in rut - became so overcharged that the old lady's toothless mouth allowed to trickle from the corners of her faintly moustachioed lips a few drops of misplaced moisture. Immediately she drew it in again with a deep sigh.'

\section{Diagnostic teeth}

Poor health or specific disease may be reflected in the teeth as noted by George Orwell ${ }^{28}$ in The Road to Wigan Pier 'The most obvious sign of under-nourishment is the badness of everybody's teeth. In Lancashire you would have to look for a long time before you saw a working-class person with good natural teeth. Indeed, you see very few people with natural teeth at all, apart from the children; and even the children's teeth have a frail bluish appearance which means, I suppose, calcium deficiency. Several dentists have told me that in industrial districts a person over thirty with any of his or her own teeth is coming to be an abnormality. In Wigan various people gave me their opinion that it is best to "get shut of" your teeth as early in life as possible. "Teeth is just a misery," one woman said to me.'

Thomas Mann ${ }^{29}$ observed signs of illhealth in Death in Venice. 'He had noted, further, that Tadzio's teeth were imperfect, rather jagged and bluish, without a healthy glaze, and of that peculiar brittle transparency which the teeth of chlorotic people often show. "He is delicate, he is sickly," Aschenbach thought. "He will most likely not live to grow old."

\section{She had two}

\section{remarkable habits, due at once to her exalted passion for the arts...and to her want of teeth}

Harry Crews ${ }^{30}$ described the use of teeth to establish chronological age. 'A mule man can always tell within a year or two how old a mule is.........A mule has a full set of teeth when he's born. But when he is two years old, he sheds two of the teeth right in the front. A good mule man can tell if he's shed those two front teeth, in which case he is between two and three years old. A really good man can tell if those teeth have just grown back in or if they've been back in the mule's mouth for several months. The next year, when he's three, the mule sheds two more teeth, one on each side of the two he shed the year before. From then on the mule sheds two teeth a year until he's five years old. That's the last time he sheds.

Then you have to go to the cups to tell his age. Mules and horses have little trenches, called cups, in the top of each tooth. Eating corn and picking up sand when they graze on grass wear down those cups. Each year they become shallower, and by the time he's ten he becomes what farmers call smoothmouthed. When the cups are entirely gone, the mule starts to get a noticeable overbite buck-toothed. From the age of ten, until the animal dies, it becomes progressively harder to get his age with much certainty. Unless you happen to be a real mule man. If you are, you can check the angle of inclination of the teeth and get his age within a year or two. About the time the mule is thirteen or fourteen, he has become about as bucktoothed as he's going to get....

Therewere men - afew - who specialised in reconditioning a mules mouth..... What the mouth doctors did was to put the cups back into the teeth with an electric drill that had a bit about the size of a matchstick. They just put a twist on the upper lip of the mule so he would stand still and then drilled a little trench in the top of each tooth. When that was done they stained the trench so that it looked as it would if it were the original. All the mouth doctors had a special stain, and they would die and go to hell before divulging how it was made.'

\section{Teeth post mortem}

Louis McNeice ${ }^{31}$ thought his teeth might have some diagnostic significance in the future

'Tuesday the Third: to the dentist. Who explains,

As always, how my growth of gums and bone

Is something quite peculiar; with some pains In both and in my mind, and having read Reports that the maxillary remains

Of some so-called ape woman, now proved dead

A million years in Africa, are delighting

The savants, my jaw too, I think, could shed

Some million years from now just as exciting Light upon something; though, of course, even then

My teeth would not be typical and the writing

Of theses in a world devoid of men

Seems rash to bank on. Time must have a stop-

And so must this poor tooth, I will tell you when

You hurt me; these same teeth must grind and chop

And grit themselves from now till Saturday The Seventh...'

Teeth as a means of identification was described by André Maurois ${ }^{32}$ 'The remains of Williams were dug out first. Standing round on the loose sand that scorched their feet, his friends watched the soldiers at work and waited 
with curiosity and horror the first appearance of the body. A black silk handkerchief was pulled out, then some shreds of linen, a boot with the bone of the leg and the foot in it, then a shapeless mass of bones and flesh. The limbs separated from the trunk on being touched. The soldiers performed their work with longhandled tongs, nippers, poles, with iron hooks, spikes, and divers other tools all resembling implements of torture.

"Is that a human body?" exclaimed Byron. "Why, it's more like the carcass of a sheep!"

He was greatly moved, and tried to hide his emotion, which he thought maudlin and unmanly, under an air of indifference. When they were lifting the skull, "Stop a moment, let me see the jaw," he said. "I can recognize by the teeth anyone with whom I have talked. I always watch the mouth, it tells me what the eyes try to conceal."

A funeral pyre had been prepared, Trelawny applied the fire, and the materials being dry and resinous the pine-wood flamed furiously, and the heat drove the spectators back. The body and skull burning fiercely, gave the flames a silvery and wavy look of indescribable brightness and purity. When the heat was a little diminished Byron and Hunt threw on to the fire frankincense, salt and wine.'

1 Trollope A. Framley Parsonage. London: JM Dent and Sons, 1906.

2 Flaubert G. Letters. London: Faber and Faber, 1979.

3 Sitwell O. The Scarlet Tree. London: Macmillan, 1946.

4 Acton H. Memoirs of an Asthete. London: Methuen, 1948.

5 Garnett D. The Golden Echo. London: Chatto and Windus, 1953

6 Barzinni L. The Italians. London: Hamish Hamilton, 1964.

7 Burgess A. Earthly Powers. London: Hutchinson and Co, 1980.

8 Harris F. Oscar Wilde: His Life and Confessions London: Constable and Co, 1938.

9 O'Faolain S. Vive Moi. London; Rupert Hart Davis, 1965.

10 Calder-Marshall A. The Magic of my Youth. London: Rupert Hart-Davis, 1951.

11 Cary J. A House of Children. London: Michael Joseph, 1941.

12 Sholokhov M. And quiet flows the Don. London: Putnam, 1934.

13 Salinger J. D. The Catcher in the Rye. London: Hamish Hamilton, 1951.

14 Sassoon S. Memoirs of an Infantry Officer. London: Faber and Faber, 1930.

15 Pritchett V. S. A Cab at the Door. London: Chatto and Windus, 1968.
16 Tyler A. Dinner at the Homesick Restaurant London: Chatto and Windus, 1982

17 Brenan G. A Life of One's Own. London: Hamish Hamilton, 1974.

18 Leigh Fermor P. A Time of Gifts. London: John Murray, 1977.

19 Dickens C. Dombey and Son. London: The Waverly Book Co, 1846.

20 Day-Lewis C. The Buried Day. London: Chatto and Windus, 1960.

21 Cocteau J. My Contemporaries. London: Peter Owen, 1967.

22 Hardy T. Under the Greenwood Tree. London: Macmillan Ltd, 1974.

23 Woolf L. Downhill all the Way. London: Hogarth press, 1967.

24 Landesman J. Rebel Without Applause. London: Bloomsbury, 1987.

25 Hardy T. Far From the Madding Crowd. London: Macmillan Ltd, 1874.

26 Hardy T. The Trumpet Major. London: Macmillan Ltd, 1912.

27 Proust M. Cities of the Plain. London: Chatto and Windus, 1981.

28 Orwell G. The Road to Wigan Pier. London: Secker and Warburg, 1937.

29 Mann T. Death in Venice. London: Martin Secker and Warburg, 1928.

30 Crews H. A Childhood. Athens, Georgia: University of Georgia Press, 1995

31 McNeice L. Autumn Sequel. London: Faber and Faber, 1938.

32 Maurios A. Ariel. London: Bodley Head, 1924. 